\title{
Pengembangan Sistem Informasi Berbasis Website (Studi Kasus: Toko Sepatu Citra Abadi)
}

\author{
Nursanti Novi Arisa ${ }^{1 *}$, M. Ihsan Alfani P. ${ }^{2}$ \\ ${ }^{1}$ Institut Teknologi Kalimantan \\ Jl. Soekarno Hatta KM 15 Karang Joang, Kota Balikpapan 76127 \\ Corresponding author's e-mail: nursanti.novi@lecturer.itk.ac.id
}

\begin{abstract}
Abstrak- Perkembangan teknologi saat ini sudah banyak memberikan perubahan. Hal ini juga ikut dimanfaatkan khususnya bagi kalangan UMKM. UMKM mendapatkan dampak yang cukup signifikan dari adanya pandemi covid 19, salah satunya adalah "Toko Sepatu Citra Abadi” di Samarinda. Terbatasnya kegiatan masyarakat untuk mengurangi dampak penyebaran covid 19 juga menyebabkan turunnya aktifitas perekonomian. Sehingga para pelaku UMKM harus terus berinovasi agar usaha yang ada saat ini tetap berjalan. Selain dari sisi pemasaran produk yang perlu dikembangkan, sisi manajamen yang masih menerapkan metode konvensional menyebabkan proses bisnis yang berjalan tidak efektif dan efisien. Oleh karena itu perlu adanya sistem informasi yang mampu mengakomodir ke dua masalah tersebut, sehingga pelaku UMKM dapat menaikkan perekonomian di tengah pandemi covid 19. Metode pengembangan sistem dilakukan dengan 4 tahapan, 1) analisa kebutuhan, 2) perancangan sistem, 3) implementasi, dan 4) pengujian. Sistem informasi berbasis web ini dapat digunakan untuk semua kalangan yang berminat untuk membeli sepatu dari toko tersebut.
\end{abstract}

Kata kunci: UMKM, Sistem Informasi, Website, Covid 19

Abstract - The development of technology today has brought many changes. This is also used, especially for the UMKM. UMKM have had a significant impact from the COVID-19 pandemic, one of which is the "Toko Sepatu Citra Abadi" in Samarinda. The limited community activities to reduce the impact of the spread of COVID-19 have also caused a decline in economic activity. So that UMKM actors must continue to innovate so that existing businesses can continue to run. Apart from the marketing side of products that need to be developed, the management side that still applies conventional methods causes the running business processes to be ineffective and inefficient. Therefore, it is necessary to have an information system that is able to accommodate these two problems, so that UMKM actors can boost the economy in the midst of the covid 19 pandemic. The system development method is carried out in 4 stages, 1) needs analysis, 2) system design, 3) implementation, and 4) testing. This web-based information system can be used for all people who are interested in buying shoes from the store.

Keywords : UMKM, Information System, Website, Covid 19

\section{Pendahuluan}

Perkembangan teknologi saat ini sudah banyak mengalami perubahan. Teknologi menjadi sesuatu yang tidak dapat terlepaskan dari kegiatan sehari-hari. Adanya teknologi juga memberikan dampak yang baik kepada berbagai kalangan, khususnya bagi pekerja yang memulai usahanya dibidang jual beli. Pandemi covid 19 yang mulai melanda Indonesia sejak tahun 2019 memberikan dampak yang cukup siginifikan bagi pelaku usaha jual beli. Terbatasnya kegiatan masyarakat untuk mengurangi dampak penyebaran covid menyebabkan menurunnya aktifitas perekonomian tidak terkecuali aktifitas pada sektor Usaha Mikro, Kecil, dan Menengah (UMKM) [1]. UMKM merupakan usaha produktif yang dapat dikembangkan untuk dapat menanggulangi kemiskinan yang bergerak di berbagai sektor bidang.

Dampak adanya covid 19 juga ikut dirasakan bagi pelaku UMKM dalam memasarkan produk jualannya. Adanya kebijakan pemerintah mengenai pemberlakuan pembatasan kegiatan masyarakat menyebabkan pelaku UMKM untuk mampu mengembangkan ide untuk menghasilkan solusi inovatif bagi perkembangan usahanya[8]. Salah satu UMKM yang juga terkena dampak dari adanya covid 19 adalah toko sepatu citra abadi. Toko sepatu citra abadi merupakan toko sepatu yang menyediakan beragam model sepatu untuk berbagai usia mulai dari anak-anak, remaja, dan orang tua. Tidak hanya itu di toko ini juga dijual berbagai jenis sepatu sesuai dengan aktifitas yang dilakukan mulai dari sepatu sekolah, sepatu santai, dan sepatu olahraga. Toko citra abadi saat ini berlokasi di Samarinda.

Sebelum adanya pandemi covid 19 strategi penjualan menerapkan cara konvensional, dimana konsumen akan langsung berkunjung ke toko jika mereka ingin membeli sepatu yang diinginkan. Namun cara konvensional ini tidak bisa lagi diterapkan sepenuhnya, karena terbatasnya kegiatan masyarakat untuk dapat bepergian. Keadaan ini memberikan dampak pada turunnya angka penjualan sepatu selama pandemi covid 19. 
Salah satu inovasi yang dapat dilakukan adalah dengan memanfaatkan teknologi dengan membuat sistem informasi berbasis website. Masalah lain yang juga dihadapi di toko citra abadi yakni proses bisnis yang masih dilakukan secara manual, seperti pendataan barang dan pengecekan barang, pembukuan, penggajian karyawan hingga transaksi jual beli. Hal ini membuat kinerja owner maupun karyawan harus membutuhkan waktu yang lama dan memiliki potensi untuk kehilangan data sewaktu-waktu.

Penelitian ini bertujuan untuk membuat sistem informasi berbasis website untuk membantu pemasaran produk dan mengefisiensikan proses manajemen yang berjalan di toko tersebut. Dengan adanya sistem informasi berbasis website ini diharapkan dapat meningkatkan angka penjualan dan memperluas jaringan konsumen dari berbagai wilayah tidak hanya berasal dari kota Samarinda, karena pembeli akan dengan mudah melihat dan membeli produk yang diminati dengan melalui sistem penjualan terpusat pada sistem informasi tersebut.

\section{Tinjauan Pustaka}

2.1. Sistem Informasi Berbasis Website

Sistem informasi digambarkan sebagai perangkat teknologi berisi informasi, proses bisnis dalam organisasi dan fungsi apa yang bisa digunakan dalam peningkatan efektivitas manajemen suatu organisasi [7][9]. Tujuan utama dari adanya sistem informasi ini adalah untuk mencapai target dari adanya sistem itu dibuat. Website merupakan situs web dari sebuah sistem informasi yang memiliki halaman yang saling terhubung [2].

2.2. MySQL

MySQL adahlahsalah satu jenisdatabase serveryang sangat populer, hal ini disebabkan karena MySQL menggunakan SQL sebagai bahasa dasar untuk mengakses databasenya. MySQL bersifat Open Source, software ini dilengkapi dengan source code (kode yang dipakai untuk membuat MySQL) [4].

2.3. Unified Modelling Language

UML merupakan sebuah metode untuk merancang model sehingga dikomunikasikan dengan mudah pada pemodel lainnya. Alasan UML menjadi bahasa baku permodelan karena UML merupakan bahasa yang independen 14 dari bahasa pemograman komputer dan perangkat lunak permodelan tertentu [3][5].

2.4. Use Case Diagram

Use Case Diagram Model ini digunakan untuk memprediksi bagaimana sistem informasi yang sedang dikembangkan akan berperilaku. Contoh bagaimana satu atau lebih aktor berinteraksi dalam sistem yang sedang dibangun menggunakan use case ditampilkan dalam use case. Memahami fungsionalitas suatu sistem dan siapa yang memiliki akses untuk memanfaatkan fungsi-fungsi ini dapat membantu pengembang lebih memahami bagaimana suatu sistem beroperasi [3].

2.5. Laravel

Laravel merupakan paradigma arsitektur MVC (Model, View, Controller), Laravel dibuat sebagai kerangka kerja PHP. Itu dirilis di bawah persyaratan lisensi MIT. Untuk membangun situs web berbasis MVP, Laravel adalah pilihan kerangka kerja PHP yang baik. Ini bertujuan untuk meningkatkan kualitas perangkat lunak dengan mengurangi biaya pengembangan dan pemeliharaan awal dan dengan menawarkan sintaks yang ekspresif, sederhana, dan hemat waktu untuk menangani aplikasi [6].

\section{Metode Penelitian}

Penelitian ini akan melalui beberapa proses dalam pengembangan sistem informasi berbasis web.

1. Analisa Kebutuhan Sistem

Pada tahap ini akan dilakukan proses identifikasi kebutuhan yang berhubungan dengan perangkat lunak berdasarkan permasalahan yang ada pada toko sepatu citra abadi. Tahapan ini diperlukan untuk dijadikan dasar dalam pengembangan sistem informasi. Analisa kebutuhan sistem akan dilakukan dari segi fungsional dan non-fungsional. Pengumpulan data yang dibutuhkan untuk kebutuhan sistem dilakukan dengan wawancara langsung kepada owner dan karyawan dari toko sepatu citra abadi.

2. Perancangan Sistem

Pada tahap dilakukan perancangan basis data dan membuat model diagram UML yaitu use case diagram untuk mengetahui hubungan antara pengguna dengan sistem yang akan dibuat.

3. Implementasi

Pada tahap ini dilakukan pengkodean sistem dan pembuatan antarmuka sistem. Pengkodean sistem dilakukan dengan bahasa pemrograman framework laravel dan MySQL untuk perancangan database.

4. Pengujian Sistem

Tahapan ini akan dilakukan pengujian hasil implementasi dengan menggunakan metode black-box testing yang akan berfokus pada hasil dari pengujian tanpa melihat dari proses yang sedang berjalan. 


\section{Hasil dan Pembahasan}

Lingkup masalah untuk perangkat lunak ini adalah suatu sistem perangkat lunak yang dibuat untuk membantu proses manajamen dari "Toko Sepatu Citra Abadi". Untuk mengembangkan sistem informasi yang sesuai dengan tujuan maka perlu dilakukan analisa kebutuhan baik dari segi fungsional dan non fungsional. Dari segi fungsional sistem informasi mencakup beberapa hal yang terdiri dari: 1). Memberikan fitur Pengelolaan Ketersediaan, yaitu fitur yang digunakan oleh produsen untuk menginput hasil penjualan dan pembelian barang keluar beserta siapa pembeli, barang apa yang dibeli, warna barang, ukuran, brand, serta tanggal dan lokasi pengiriman. 2). Memberikan fitur Saran dan kritik, yaitu fitur yang digunakan agar pelanggan bisa memberikan saran, kritik serta pendapatnya mengenai produk yang dihasilkan, sehingga produk dapat lebih baik. 3). Memberikan fitur Goods, yaitu fitur yang digunakan untuk menginput barang baru dengan cara input file yang berisi list-list barang ataupun secara manual dan dapat menginput metode pembayaran serta dapat menginput barang promo. 4). Memberikan fitur Transaksi, yaitu fitur yang digunakan untuk melakukan transaksi antara produsen dan konsumen. Selain dari segi fungsional, analisis kebutuhan juga ditinjau dari segi non fungsional. Adapun spesifikasi hardware yang dibutuhkan ditunjukkan pada Tabel 1.

Tabel 1. Spesifikasi Hardware yang Dibutuhkan

\begin{tabular}{|l|l|}
\hline Processor & Intel (R) Core (TM) i7-9750H, 2.60 GHz \\
\hline RAM & $16 \mathrm{~GB}$ \\
\hline
\end{tabular}

Setelah tahap analisa kebutuhan selanjutnya masuk ke tahap perancangan sistem. Pada tahap ini dilakukan perancangan model konseptual untuk mengetahui hubungan antara pengguna dengan sistem yang akan dibuat dalam bentuk Usecase diagram dan Entity Relationship Diagram. Adapun use case diagram ditunjukkan pada Gambar 1 dan ERD ditunjukkan pada Gambar 2. Selanjutnya untuk aktor dari sistem ini terdari 4 yaitu, administrator, karyawan, pembeli, dan pengguna umum. 1) Administrator merupakan aktor yang mempunyai wewenang untuk memasukkan username dan password, menambah, melihat, mengubah, menghapus data barang, menanggapi pertanyaan FAQ, melihat penjualan semua barang, melakukan transaksi dari barang yang dibeli. Memproses barang yang dibeli, menambah, mengubah, menghapus data karyawan, melihat data profil pembeli, dan menghapus profil pembeli. 2) Karyawan merupakan aktor yang memiliki wewenang untuk menanggapi FAQ, melihat data barang, melihat data penjualan semua barang, memproses barang yang dibeli, melakukan transaksi barang yang dibeli, merekap data penjualan semua barang, dan dapat melihat data profil pembeli. 3) Pembeli merupakan aktor yang memiliki wewenang untuk memasukkan username dan password, memberikan pertanyaan FAQ, melihat data barang, melakukan transaksi barang yang dibeli, melihat. Menambah, mengubah, menghapus data pembelian, melihat, menambah, mengubah, menghapus data profil pembeli, dan melakukan pendaftaran sebagai pelanggan. 4) Pengguna umum merupakan aktor yang memiliki wewenang untuk melihat data barang, melakukan pendaftaran sebagai pelanggan, dan memasukkan username/password. 


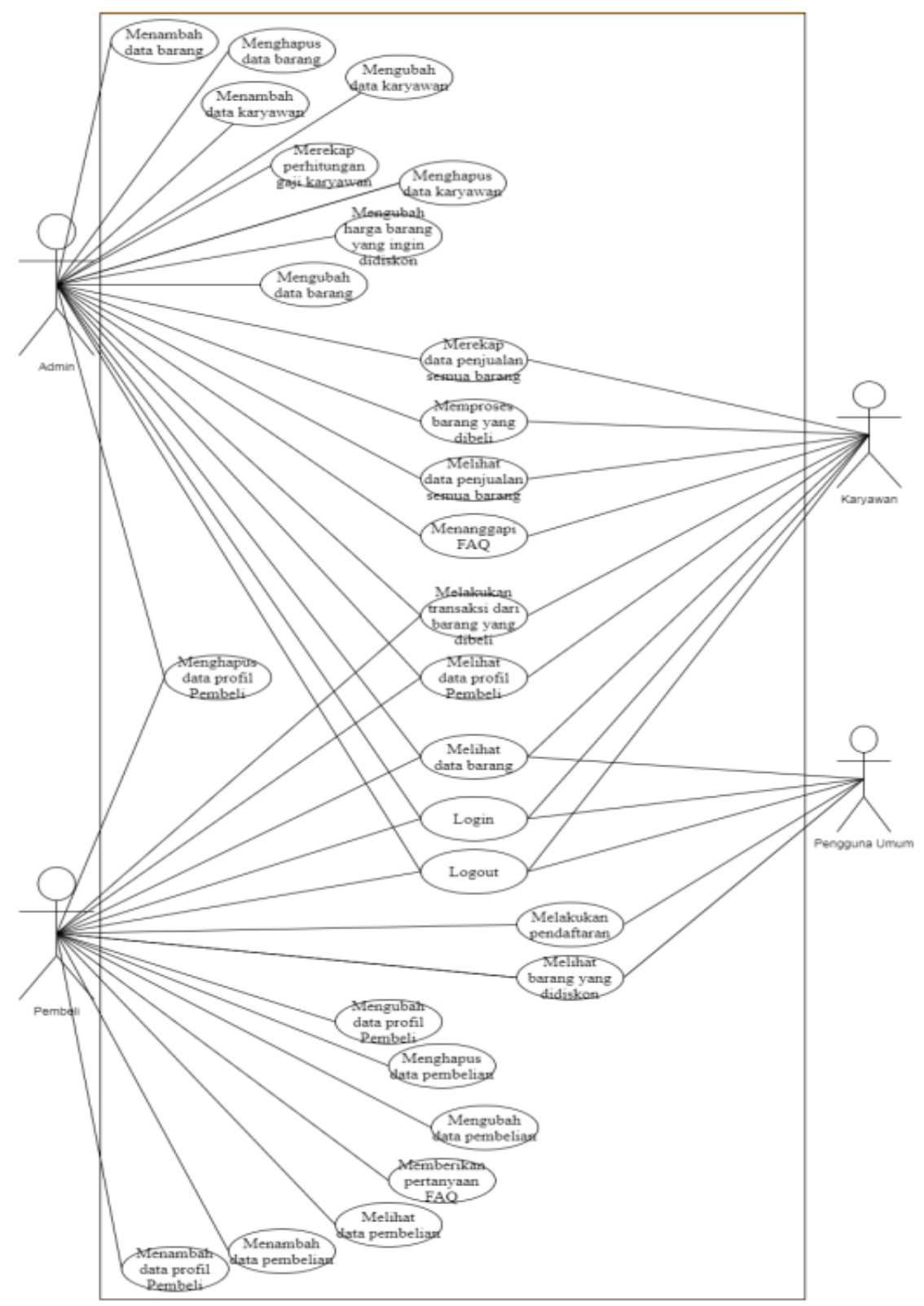

Gambar 1. Use Case Diagram 


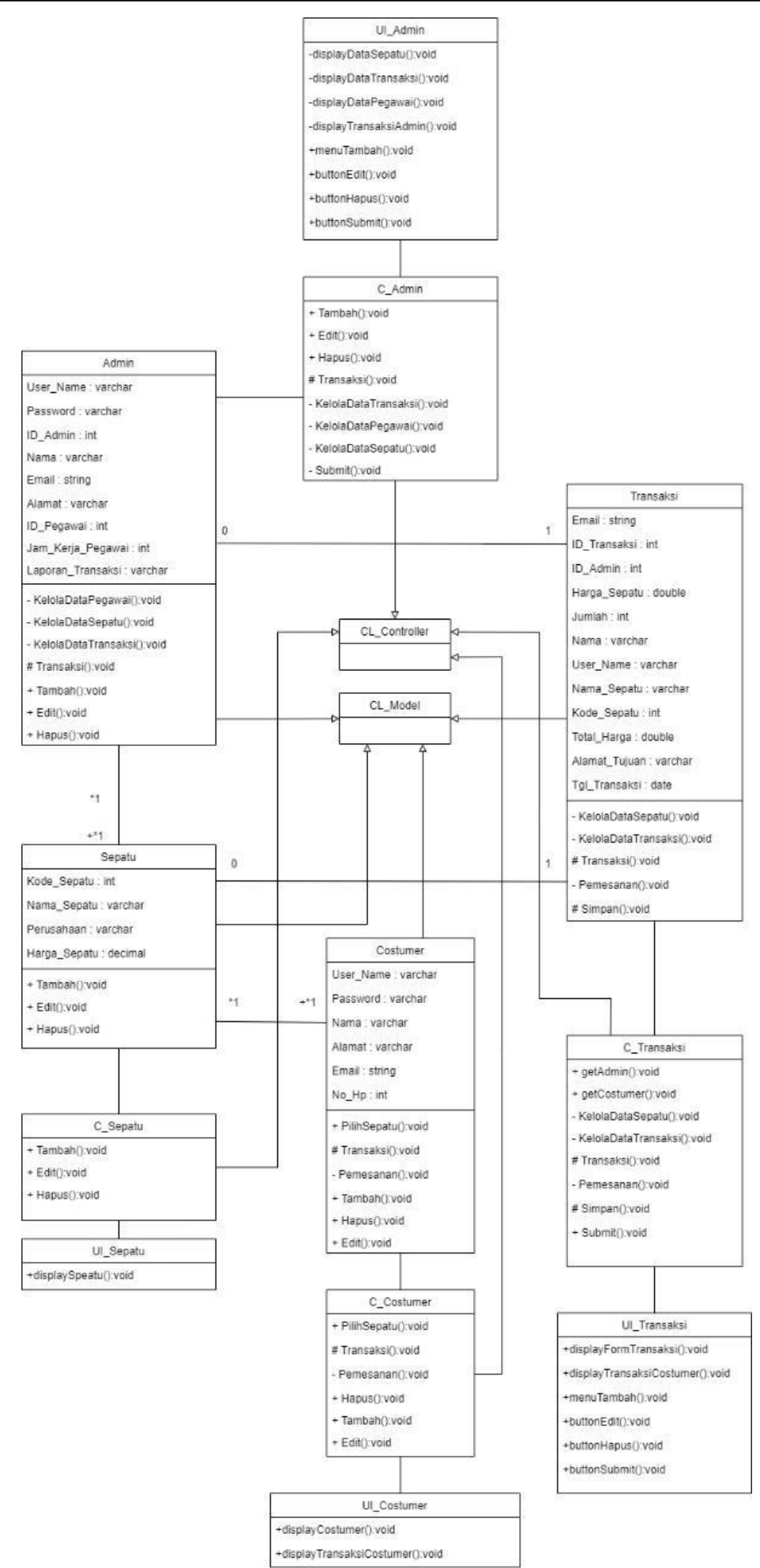

Gambar 2. ERD

Setelah tahapan perancangan telah selesai dilakukan, selanjutnya masuk pada tahapan implementasi. Pada tahapan ini dilakukan proses pengkodean sistem dan perancangan antarmuka yang menyesuaikan keinginan owner yakni simple dan mudah digunakan. Sistem dibuat dengan menggunakan framework Laravel dan MySQL untuk pembuatan basis data. Berikut ditunjukkan tampilan antarmuka dari Sistem Informasi Toko Sepatu Citra Abadi berbasis web. Pada halaman login pengguna akan diarahkan untuk mengisi username dan password sebelum mengakses web tersebut. Bagi pengunjung yang belum mendaftar akan diarahkan untuk 
melakukan register terlebih dahulu dengan memasukkan informasi terkait nama lengkap, alamat, email, username, password, dan konfirmasi password.

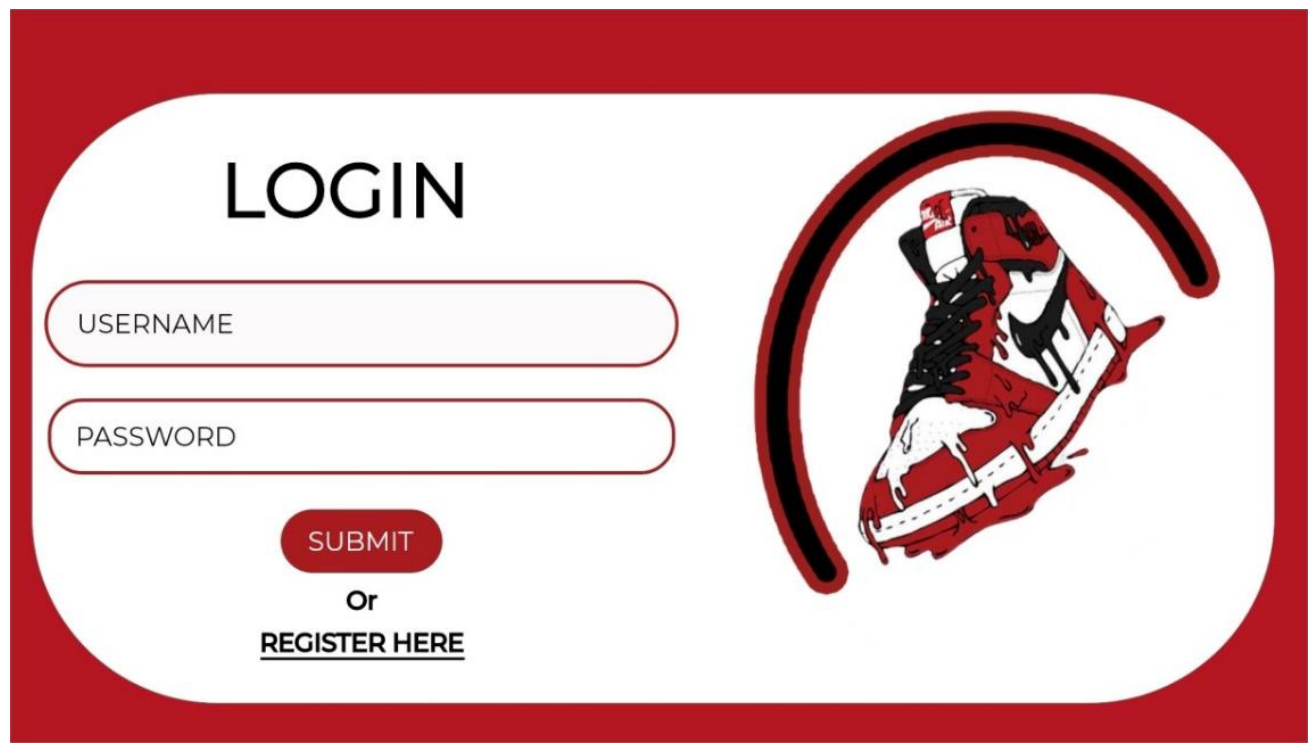

Gambar 3. Perancangan Antarmuka Login

Dari halaman login selanjutnya pembeli akan diarahkan ke halaman user untuk melihat produk yang tersedia di toko. Selanjutnya, jika pembeli ingin melalukan transaksi pembelian maka user tinggal memilih produk yang disukai. Disana akan ditunjukkan informasi terkait produk yang akan dibeli. Untuk proses selanjutnya pembeli tinggal mengklik tombol buy jika berminat untuk membeli. Selain itu sistem informasi ini juga dilengkapi dengan laman FAQ yang berfungsi untuk memberikan arahan kepada pembeli dalam melakukan transaksi jual beli.

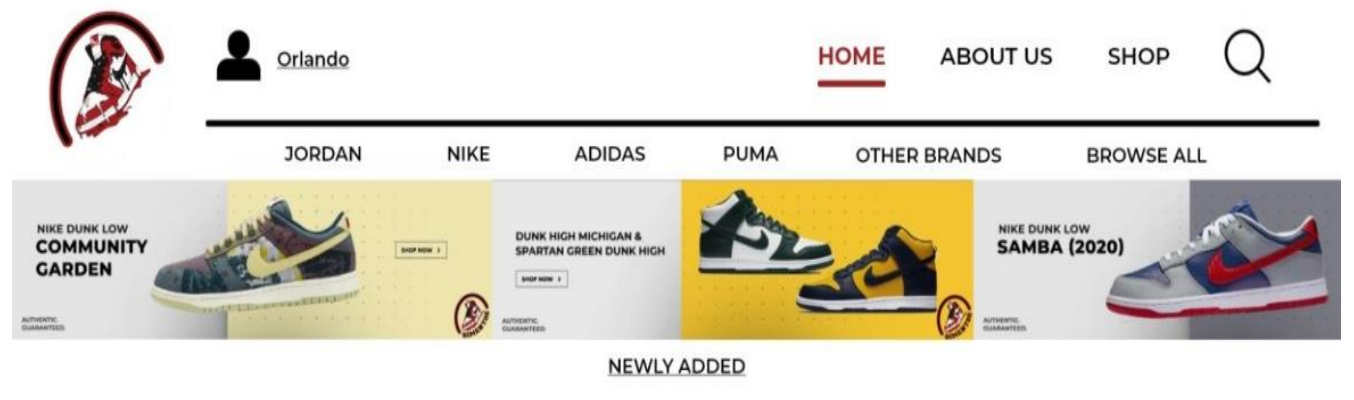

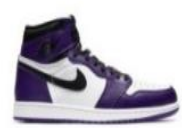

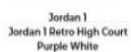

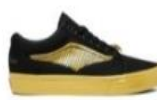

vans $x$ Harry Ponster old Shood
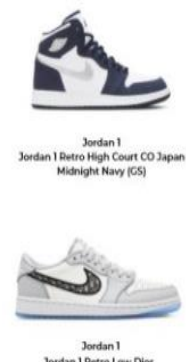
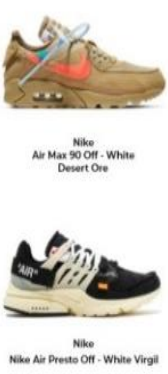
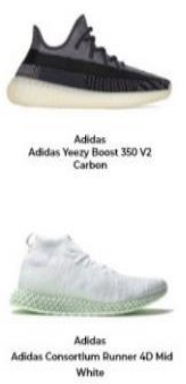

Gambar 4. Perancangan Antarmuka Home Users 


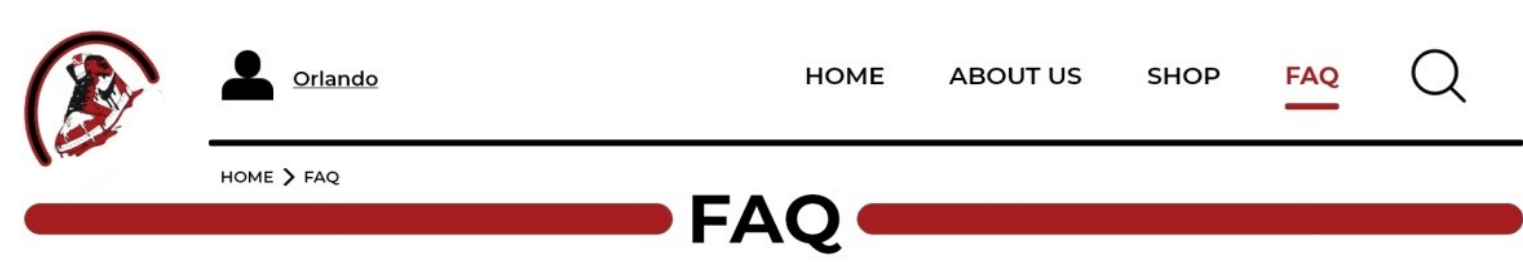

TANYA JAWAB

\begin{tabular}{lr} 
Dimana kah toko Citra Abadi berada ? & $\checkmark$ \\
\hline Haruskah melakukan registrasi di SIMENTOS untuk melakukan pembelian ? & $\checkmark$ \\
\hline Apakah keuntungan dengan membuat akun / registrasi di SIMENTOS ? & $\checkmark$ \\
\hline Apakah barang - barang yang di jual merupakan barang original ? & $\checkmark$ \\
\hline Apakah semua barang yang di jual adalah barang baru ? & $\checkmark$ \\
\hline Bagaimana cara mencari barang yang diinginkan ? & SUBMIT
\end{tabular}

Gambar 6. Perancangan Antarmuka FAQ

Tahapan terkahir dari penelitian ini adalah melakukan pengujian terhadap sistem. Hal ini dilakukan untuk membuktikan apakah sistem yang diimplementasikan telah memenuhi spesifikasi dan rancangan yang sudah direncanakan sebelumnya. Pengujian dilakukan dengan menggunakan metode black box testing. Adapun hasil pengujian yang telah dilakukan ditunjukkan pada Tabel 2 sebagai berikut.

Tabel 2. Hasil Pengujian Sistem

\begin{tabular}{|c|c|c|c|}
\hline No. & Nama Pengujian & Proses Pengujian & Hasil Pengujian \\
\hline 1. & $\begin{array}{l}\text { Use case Menambah data } \\
\text { barang }\end{array}$ & Administrator menambahkan data barang & Berhasil \\
\hline 2. & $\begin{array}{l}\text { Use case Melihat data } \\
\text { barang }\end{array}$ & Administrator melihat data barang & Berhasil \\
\hline 3. & $\begin{array}{l}\text { Use case Mengubah data } \\
\text { barang }\end{array}$ & Administrator mengubah data barang & Berhasil \\
\hline 4. & $\begin{array}{c}\text { Use case Menghapus data } \\
\text { barang }\end{array}$ & Administrator menghapus data barang & Berhasil \\
\hline 5. & Use case Login & Administrator dapat melakukan login & Berhasil \\
\hline 6. & Use Case FAQ & $\begin{array}{l}\text { Administrator dapat menanggapi pertanyaan } \\
\text { dari pembeli }\end{array}$ & Berhasil \\
\hline 7. & $\begin{array}{l}\text { Use case Melihat Data } \\
\text { Penjualan semua barang }\end{array}$ & Adminitrator dapat melihat data semua barang & Berhasil \\
\hline 8. & $\begin{array}{l}\text { Use case Melakukan } \\
\text { transaksi barang yang dibeli }\end{array}$ & Administrator dapat melakukan transaksi & Berhasil \\
\hline 9. & $\begin{array}{l}\text { Use Case Memproses } \\
\text { Barang Yang Dibeli }\end{array}$ & $\begin{array}{l}\text { Administrator dapat memproses barang yang } \\
\text { dibeli }\end{array}$ & Berhasil \\
\hline 10. & Use Case Logout & Administrator dapat keluar & Berhasil \\
\hline 11. & $\begin{array}{l}\text { Use Case Merekap Data } \\
\text { Penjualan Semua Barang }\end{array}$ & $\begin{array}{l}\text { Administrator dapat merekap data penjualan } \\
\text { semua barang }\end{array}$ & Berhasil \\
\hline 12. & $\begin{array}{l}\text { Use Case Melihat Data } \\
\text { Profil Pembeli }\end{array}$ & $\begin{array}{l}\text { Administrator dapat Login dan ingin melihat } \\
\text { data profil pembeli }\end{array}$ & Berhasil \\
\hline 13. & $\begin{array}{c}\text { Use Case Menghapus Data } \\
\text { Profil Pembeli }\end{array}$ & Administrator dapat menghapus profil pembeli & Berhasil \\
\hline 14. & $\begin{array}{c}\text { Use Case Memberikan } \\
\text { Pertanyaan FAQ }\end{array}$ & Pembeli dapat memberikan pertanyaan FAQ & Berhasil \\
\hline 15. & $\begin{array}{l}\text { Use Case Melihat Data } \\
\text { Pembelian }\end{array}$ & Pembeli melihat list data pembelian & Berhasil \\
\hline
\end{tabular}




\begin{tabular}{|c|c|c|c|}
\hline 16. & $\begin{array}{c}\text { Use Case Menambah Data } \\
\text { Pembelian }\end{array}$ & Pembeli menambah data pembelian & Berhasil \\
\hline 17. & $\begin{array}{c}\text { Use Case Mengubah Data } \\
\text { Pembelian }\end{array}$ & Pembeli dapat Mengubah Data Pembelian & Berhasil \\
\hline 18. & $\begin{array}{c}\text { Use Case Menghapus Data } \\
\text { Pembelian }\end{array}$ & Pembeli dapat Menghapus Data Pembelian & Berhasil \\
\hline No. & Nama Pengujian & Proses Pengujian & Hasil Pengujian \\
\hline 19. & $\begin{array}{c}\text { Use Case Menambah Data } \\
\text { Profil Pembeli }\end{array}$ & Pembeli dapat Menambah Data Profil Pembeli & Berhasil \\
\hline 20. & $\begin{array}{c}\text { Use Case Mengubah Data } \\
\text { Profil Pembeli }\end{array}$ & Pembeli dapat Mengubah Data Profil Pembeli & Berhasil \\
\hline 21. & $\begin{array}{c}\text { Use Case Melakukan } \\
\text { Pendaftaran }\end{array}$ & Pembeli dapat Melakukan pendaftaran & Berang \\
\hline
\end{tabular}

\section{Kesimpulan}

Berdasarkan penelitian yang telah dilakukan, maka kesimpulan yang dapat diambil sebagai berikut.

1. Dengan adanya sistem informasi berbasis web, maka sistem manajamen dari toko sepatu citra abadi dapat dilakukan lebih efektif dan efisien.

2. Proses pemasaran produk dapat menjangkau konsumen dari luar Samarinda.

3. Dapat meningkatkan pendapatan ekonomi pelaku usaha produk UMKM.

\section{Daftar Pustaka}

[1] A. F. Thaha, "Dampak Covid-19 Terhadap UMKM di Indonesia," J. Lentera Bisnis, vol. 2, no. 1, pp. 147-153, 2020.

[2] Elgamar. (2020). Buku Ajar Konsep Dasar Pemograman Website Dengan PHP. Malang: CV. Multimedia Edukasi.

[3] Mesran. (2019). Merancang Aplikasi Penjualan dengan Visual Basic. Medan: Green Press.

[4] Novendri, M. S., Saputra, A., \& Firman, C. E. (2019). Aplikasi Inventaris Barang Pada Mts Nurul Islam Dumai Menggunakan Php Dan Mysql. lentera dumai, 10(2).

[5] Purnomo, H. (2019). Pemodelan dan simulasi untuk pengelolaan adaptif sumber daya alam dan lingkungan. Bogor: PT Penerbit IPB Press.

[6] Supardi, Y. (2019). Semua Bisa Menjadi Programmer Laravel Basic. Jakarta: PT Elex Media Komputindo.

[7] Suprihadi, E. (2020). Sistem Informasi Bisnis Dinia Versi 4.0. Yogyakarta: Penerbit Andi.

[8] R. Jumardi and A. Nugroho, "Aplikasi Mading Digital Sebagai Media Promosi Produk Pelaku Usaha Mikro, Kecil Dan Menengah,” J. Nas. Komputasi dan Teknol. Inf., vol. 4, no. 6, pp. 501-508, 2021.

[9] D. Satria, Zulfan, S. Yana, and Julijar, "Perancangan SIstem Informasi Manajemen Pembelian dan Penjualan Komoditas Perkebunan Masyarakat Pada UD.Bintang Baru," J. Manaj. dan Akunt., vol. 4, no. 1, pp. 39-47, 2018.

[10] S. Safril, Z. Zulfan, and D. Satria, "SISTEM INFORMASI RINCIAN PERBAIKAN ALAT BERAT TERINTEGRASI SISTEM NOTIFIKASI BERBASIS LAYANAN GSM (Global System for Mobile Communication) PADA CV. CIPTA KARYA GROUP," Karya Ilm. Fak. Tek., vol. 1, no. 1, pp. 7-14, 2021. 